\title{
ANALISIS TIPOLOGI WILAYAH DALAM MENDUKUNG PENGEMBANGAN MINAPOLITAN DI PROVINSI GORONTALO
}

\section{Regional Typhology Analysis for Developing of Minapolitan in the Gorontalo Province}

\author{
Taslim Arifin ${ }^{1}$ Terry L. Kepel', Syahrial Nur Amri ${ }^{1}$ dan Siti Hajar Suryawati ${ }^{2}$ \\ ${ }^{1}$ Pusat Penelitian dan Pengembangan Sumberdaya Laut dan Pesisir \\ Jl. Pasir Putih I, Ancol Timur, Jakarta 14430 \\ Telp: (021) 64711672/853; Fax: (021) 64711654 \\ ${ }^{2}$ Balai Besar Penelitian Sosial Ekonomi Kelautan dan Perikanan \\ Jl. KS. Tubun Petamburan VI, Jakarta 10260 \\ Telp: (021) 53650162; Fax: (021) 53650159 \\ Diterima 5 Januari 2013 - Disetujui 31 Mei 2013
}

\begin{abstract}
ABSTRAK
Pengembangan wilayah dengan pendekatan minapolitan sebagai konsep pembangunan perikanan tidak bisa dilakukan secara parsial. Perikanan harus dibangun secara holisitik yaitu dengan membangun semua yang tersedia di perkotaan ke perdesaan. Penelitian ini bertujuan untuk mengetahui struktur dan pola pertumbuhan ekonomi wilayah dan mengetahui potensi dan daya saing lokasi sebagai prioritas pusat pertumbuhan perikanan di Provinsi Gorontalo. Studi ini menggunakan analisis tipologi Klassen dan Shift-Share (S-S). Wilayah yang memiliki struktur ekonomi relatif baik adalah Kabupaten Pohuwato. Daerah ini memiliki PDRB perkapita di atas nilai provinsi namun pertumbuhan ekonomi masih dibawah provinsi (high income but low growth), atau termasuk kategori daerah maju tapi tertekan. Kabupaten Gorontalo, Boalemo dan Bone Bolango termasuk dalam kategori relatif tertinggal (low growth and low income). Kabupaten Boalemo, Pohuwato dan Bone Bolango memiliki pertumbuhan subsektor perikanan yang hampir sama yaitu $18,6 \%, 16,2 \%$ dan $12,7 \%$. Kabupaten Gorontalo hanya bertumbuh sebesar $7,4 \%$. Hal ini tidak terlepas dari produksi subsektor perikanan Kabupaten Gorontalo yang hanya memiliki share $8 \%$ terhadap produksi perikanan. Untuk meningkatkan pertumbuhan ekonomi pada sektor perikanan, perlu memperhatikan hal-hal berikut: (a) menyediakan fasilitas publik, (b) pengembangan sektor perikanan secara terintegrasi, (c) pengembangan industri pengolahan hasil perikanan, (d) Pemda Kabupaten Boalemo dan Pohuwato, perlu melakukan tindakan pro aktif dan konstruktif untuk merangsang tumbuhnya minat penanaman modal disertai dengan peningkatan dan pembenahan kualitas SDM.
\end{abstract}

Kata Kunci: tipologi, minapolitan, pertumbuhan perikanan, Propinsi Gorontalo

\section{ABSTRACT}

Regional development by using Minapolitan approach is as a fisheries development concept cannot be applied partially. Fisheries sector should be holistically developed by developing all of potency of rurals and urban areas. This study aims to: (1) understand the structure and pattern of regional economic growth, (2) find out the potency and competitiveness of the area as a priority for fisheries development center in Gorontalo Province. This study uses Klassen and Shift-Share (S-S) typology analysis. Finding of this study showed that has the better economic structure was Pohuwato Regency. This region has Gross Regional Domestic Bruto (GRDB) per capita above the provincial value. However, economic development is still below the provincial level (high income but low growth). It is categorized as developed region but they still under preasure of economy. Boalemo Regency, Pohuwato Regency and Bone Bolango Regency have almost equal fishery development value, which are $18.6 \%, 16.2 \%$ and $12.7 \%$ respectively. Gorontalo Regency is grow only $7.4 \%$. This is due to fisheries production in Gorontalo Regency is only share $8 \%$ of total fisheries production. In order to improve economic growth, is fisheries sector need to pay attention to several important points: (a) provide public facilities, (b) development of an integrated fisheries sector, (c) development of processing industry, (d) Boalemo dan Pohuwato regencies, need to tae action of pro-active and constructive to stimulate investor in improving quality of human resources.

Keywords: typhology, minapolitan, fisheries development, Gorontalo Province 


\section{PENDAHULUAN}

Konsep minapolitan pada dasarnya hampir sama dengan agropolitan, perbedaan dasar terletak pada sektor perikanan sebagai basis perekonomian, dengan komoditas unggulan daerah masing-masing. Secara esensial, sasaran program minapolitan meliputi: (1) pelayanan secara terpadu dan efisien dari instansi pusat dan daerah serta instansi lintas-sektor pada kawasan minapolitan; (2) berkembangnya sektor ekonomi dari komoditas sektor perikanan; (3) kawasan sentra minapolitan bersama wilayah sekitarnya tumbuh sebagai kota mandiri; dan (4) pengisian tenaga kerja pada wilayah sekitar sentra minapolitan sesuai dengan kapasitas daya dukung produksi perikanan (KepMen KP No. 18/Men/2011). Berdasarkan Keputusan Menteri Kelautan No. 32/Men/2010 dan No.39/Men/2011, Provinsi Gorontalo ditetapkan sebagai salah satu kawasan minapolitan.

Pendekatan pembangunan ekonomi-wilayah berbasis minapolitan yang diimplementasikan dengan pilar utama penggerak ekonomi yaitu sektor perikanan dan diharapkan dapat menarik perkembangan sektor-sektor yang lainnya. Dalam konsep minapolitan, fungsi kota lebih dititikberatkan sebagai pusat kegiatan non perikanan dan pusat administrasi, bukan sebagai pusat pertumbuhan. Sementara itu, desalah yang diarahkan sebagai pusat pertumbuhan. Berkembangnya kota sebagai pusat pertumbuhan temyata tidak memberikan trickle down effect, tetapi justru menimbulkan efek pengurasan sumberdaya dari wilayah sekitarnya (backwash effect) (Rustiadi dan Hadi, 2004).

Untuk mencapai pembangunan ekonomi yang baik, kota dan desa harus berperan dan menjalankan fungsi-fungsi tersebut. Kebijakan pembangunan perdesaan yang dilakukan selama ini belum mampu memberikan perubahan yang signifikan terhadap peningkatan kesejahteraan masyarakat. Glasson (1990) mengatakan bahwa kemakmuran suatu wilayah berbeda dengan wilayah lainnya. Karenanya, pengembangan kawasan minapolitan diharapkan dapat memberikan solusi bagi masalah perdesaan tersebut. Menurut Lewis (2004); Budd dan Whimster (2005) dan Razin et al. (2007), keterkaitan antara kota metropolitan dengan metro terjadi terutama melalui penyediaan tenaga kerja, yang menimbulkan aktifitas commuting, dan sektor komersial lainnya. Tujuan penelitian ini adalah (1) untuk mengetahui struktur dan pola pertumbuhan ekonomi wilayah; (2) untuk mengetahui potensi dan daya saing lokasi sebagai prioritas pusat pertumbuhan sektor perikanan di Provinsi Gorontalo.

\section{METODOLOGI}

\section{Lokasi dan Waktu Penelitian}

Lokasi pengambilan data terletak di wilayah Kabupaten Gorontalo, Bone Bolango, Boalemo dan Pohuwato Provinsi Gorontalo (Gambar 1). Penelitian ini dilaksanakan pada bulan April Agustus 2012.

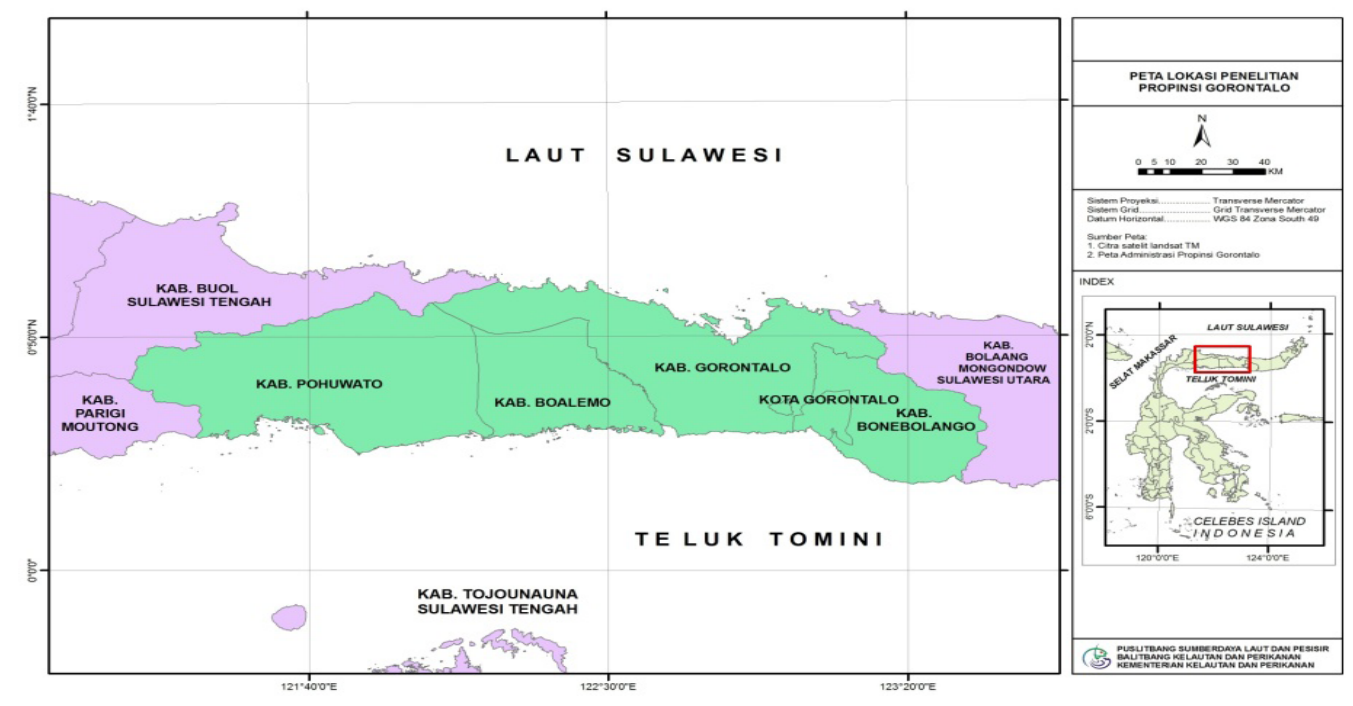

Gambar 1. Peta Lokasi Penelitian

Figure 1. Map of Research 


\section{Jenis dan Sumber Data}

Data yang dikumpulkan berupa data sekunder dalam bentuk dokumen, yaitu laporanlaporan hasil penelitian terdahulu, dan laporanlaporan teknis maupun bentuk publikasi lain yang diperoleh dari instansi terkait seperti Badan Pusat Statistik, Badan Perencanaan dan Pembangunan Daerah (Bappeda) dan Dinas Perikanan dan Kelautan. Jenis data yang dikumpulkan tersebut meliputi: pertumbuhan ekonomi, PDRB per kapita, struktur perekonomian daerah dan data produksi perikanan.

\section{Analisis Data}

\section{Analisis Tipologi Klassen}

Analisis tersebut untukmengetahuigambaran pola dan struktur pertumbuhan ekonomi ekonomi daerah (Sutikno dan Maryunani, 2007), atau tipologi pertumbuhan (Sjafrizal, 1997). Lebih lanjut Sjafrizal (1997), membedakan empat karakteristik pertumbuhan daerah, yaitu : (1) daerah maju dan bertumbuh cepat (rapid growth region); (2) daerah maju tetapi tertekan (retarded region); (3) daerah sedang bertumbuh (growing region) dan (4) daerah relatif tertinggal (stagnant region). Sementara itu Kuncoro (1997) dalam (Sutikno dan Maryunani, 2007), menggunakan alat analisis tersebut untuk menunjukkan kinerja pertumbuhan ekonomi 27 propinsi di Indonesia. Dengan membandingkan ratio pendapatan perkapita dan ratio pertumbuhan. Dalam penelitiannya perekonomian propinsi di Indonesia diklasifikasikan ke dalam 4 kelompok. 1) Low growth, high income, 2) High growth, high income, 3) High growth, low income dan 4) Low growth, low income.

\section{Analisis Shift Share}

Analisis Shift Share digunakan untuk mengidentifikasi dan menganalisis keunggulan kompetitif suatu komoditas, dimana keunggulan kompetitif merupakan kemampuan suatu daerah untuk memasarkan produknya diluar daerah, luar negeri atau pasar global (Robinson, 2005). Hasil perhitungan tersebut menunjukkan indikator kemampuan persaingan (Blakely dan Leigh, 2010), bentuk persamaannya adalah sebagai berikut.

$$
D S_{i j}=\frac{X_{i j(t 1)}}{X_{i j(t 0)}}-\frac{X_{i(t 1)}}{X_{i(t 0)}}
$$

dimana:

\footnotetext{
Xij : Produksi komoditas tertentu (i) di suatu kabupaten (j) / Production of specific commodity (i) at a regency (j)
}

Xi : Total produksi komoditas (i) tertentu di provinsi / Total production of commodity (i) at a Province

t1 : Titik tahun akhir (2010) / Point in the final

t0 : Titik tahun awal (2008) / Point early years

Hasil analisis tersebut diinterpretasikan;

Jika nilai $D S_{i j}>0$, maka komoditas ke-j di kabupaten ke-i mempunyai tingkat pertumbuhan di atas tingkat pertumbuhan rata-rata komoditas ke-j di Provinsi Gorontalo. Hal itu juga menunjukkan bahwa komoditas tersebut mempunyai nilai competitivenes (persaingan) yang tinggi.

Jika nilai $D S_{i j}<0$, maka hal tersebut menunjukkan bahwa komoditas yang dimaksud mempunyai tingkat persaingan yang rendah dibandingkan dengan komoditas yang lain. Komoditas di kabupaten ke-i yang mempunyai nilai negatif berarti bahwa komoditas tersebut tingkat pertumbuhannya di bawah komoditas yang sama secara umum di provinsi. Oleh karenanya pengembangan komoditas tersebut di kabupaten ke-i tidak akan menguntungkan karena tidak mampu bersaing dengan kabupaten lain dalam provinsi.

\section{TIPOLOGI WILAYAH KABUPATEN DALAM PROPINSI GORONTALO}

Dengan menggunakan data pertumbuhan ekonomidan PDRB perkapita, maka dapat dijelaskan tentang struktur ekonomi suatu wilayah berdasarkan daerah referensinya (Priana dan Farida, 2005; Hidayati, 2008). Demikian halnya struktur ekonomi di Provinsi Gorontalo, pertumbuhan ekonomi dan PDRB perkapita Kabupaten Gorontalo, Boalemo, Pohuwato dan Bone Bolango dibandingkan dengan capaian tingkat provinsi sebagai daerah referensi. Keadaan laju pertumbuhan ekonomi dan PDRB perkapita masing-masing wilayah dapat dilihat pada Tabel 1, sedangkan laju pertumbuhan ekonomi subsektor perikanan dan produksi perikanan disajikan pada Tabel 2.

Dari Tabel 1, wilayah yang memiliki struktur ekonomi relatif baik adalah Kabupaten Pohuwato. Menurut Wijaya dan Atmanti (2006), kawasan andalan merupakan kawasan yang ditetapkan sebagai penggerak perekonomian wilayah. Daerah ini memiliki PDRB perkapita di atas nilai provinsi namun pertumbuhan ekonomi masih dibawah provinsi (high income but low growth), 
atau termasuk kategori daerah maju tapi tertekan. Kabupaten Gorontalo, Boalemo dan Bone Bolango termasuk dalam kategori relatif tertinggal (low growth and low income). Hal ini berlangsung konstan selama tahun 2008-2010, tidak ada daerah yang mampu mencapai kuadran pertama (high growth and high income). Dengan membandingkan nilai pertumbuhan ekonomi dan PDRB perkapita setiap kabupaten dengan nilai provinsi pada tabel 1 di atas, dapat diklasifikasi dalam 4 kategori, yaitu: (1) Kuadran I: HGHI; High growth and high income (daerah cepat maju dan cepat tumbuh); (2) Kuadran II: HILG; High income but low growth (daerah maju tapi tertekan);
(3) Kuadran III: HGLI; High growth but low income (daerah berkembang cepat) dan (4) Kuadran IV: LGLI; Low growth and low income (daerah relatif tertinggal).

Pemetaan sektoral akan mengklasifikasikan perekonomian dalam 4 kategori (income per capita diganti dengan produksi perikanan) yaitu HGHP, HPLG, HGLP dan LGLP. Dari perbandingan perkembangan yang terjadi pada subsektor perikanan (laju pertumbuhan dan produksi perikanan) pada (Gambar 2) dapat dikonversi dalam matriks tipologi Klassen dan scatter plot pada (Tabel 3) berikut:

Tabel 1. Laju Pertumbuhan Ekonomi dan PDRB Perkapita Provinsi Gorontalo. 2008-2010. Table 1. Economic Growth Rate and GDP Per Capita Gorontalo Province. 2008-2010.

\begin{tabular}{|c|c|c|c|c|c|c|c|c|}
\hline \multirow{2}{*}{$\begin{array}{l}\text { Wilayah/ } \\
\text { Region }\end{array}$} & \multicolumn{4}{|c|}{$\begin{array}{c}\text { Pertumbuhan Ekonomi (\%)/ } \\
\text { Economic Growth (\%) }\end{array}$} & \multicolumn{4}{|c|}{$\begin{array}{l}\text { PDRB Perkapita (Rupiah)/ } \\
\text { GDP Per Capita (Rupiah) }\end{array}$} \\
\hline & 2008 & 2009 & 2010 & Mean & 2008 & 2009 & 2010 & Mean \\
\hline $\begin{array}{l}\text { Kab. Gorontalo/ } \\
\text { Gorontalo Regency }\end{array}$ & 7.63 & 7.48 & 7.62 & 7.58 & $2,144,837$ & $2,275,659$ & $2,420,656$ & $2,280,384$ \\
\hline $\begin{array}{l}\text { Kab. Boalemo/ } \\
\text { Boalemo Regency }\end{array}$ & 7.37 & 6.14 & 6.4 & 6.64 & $2,293,709$ & $2,418,403$ & $2,578,236$ & $2,430,116$ \\
\hline $\begin{array}{l}\text { Kab. Pohuwato/ } \\
\text { Pohuwato Regency }\end{array}$ & 7.41 & 7.16 & 7.45 & 7.34 & $3,733,139$ & $3,876,431$ & $4,047,356$ & $3,885,642$ \\
\hline $\begin{array}{l}\text { Kab. Bone Bolango/ } \\
\text { Bone Bolango Regency }\end{array}$ & 6.34 & 6.49 & 6.66 & 6.50 & $1,899,875$ & $1,995,954$ & $1,977,013$ & $1,957,614$ \\
\hline $\begin{array}{l}\text { Provinsi Gorontalo/ } \\
\text { Gorontalo Province }\end{array}$ & 7.76 & 7.54 & 7.63 & 7.64 & $2,526,917$ & $2,658,649$ & $2,804,838$ & $2,663,468$ \\
\hline
\end{tabular}

Sumber: BPS Provinsi Gorontalo. 2011 / Source : BPS Gorontalo Province. 2011

Tabel 2. Laju Pertumbuhan Ekonomi Subsektor Perikanan dan Produksi Perikanan Provinsi Gorontalo, 2008-2010.

Table 2. Economic Growth Sub-sectors of Fishery and Fisheries Production Gorontalo Province, 2008-2010.

\begin{tabular}{|c|c|c|c|c|c|c|c|c|}
\hline \multirow{2}{*}{$\begin{array}{c}\text { Wilayah/ } \\
\text { Region }\end{array}$} & \multicolumn{4}{|c|}{$\begin{array}{l}\text { LPE Subsektor Perikanan (\%)I } \\
\text { LPE Fishery Sub-sector (\%) }\end{array}$} & \multicolumn{4}{|c|}{$\begin{array}{l}\text { Produksi Perikanan (Ton)/ } \\
\text { Fisheries Production (Ton) }\end{array}$} \\
\hline & 2008 & 2009 & 2010 & Mean & 2008 & 2009 & 2010 & Mean \\
\hline $\begin{array}{l}\text { Kab. Gorontalo/ } \\
\text { Gorontalo Regency }\end{array}$ & 7.78 & 2.28 & 4.99 & 5.02 & 7,302 & 6,634 & 10,094 & 8,010 \\
\hline $\begin{array}{l}\text { Kab. Boalemo/ } \\
\text { Boalemo Regency }\end{array}$ & 4.47 & 14.6 & 3.52 & 7.53 & 19,930 & 18,299 & 42,989 & 27,073 \\
\hline $\begin{array}{l}\text { Kab. Pohuwato/ } \\
\text { Pohuwato Regency }\end{array}$ & 8.65 & 8.93 & 6.69 & 8.09 & 19,144 & 12,542 & 50,032 & 27,239 \\
\hline $\begin{array}{l}\text { Kab. Bone Bolango/ } \\
\text { Bone Bolango Regency }\end{array}$ & 2.11 & 5.73 & 6.57 & 4.80 & 9,643 & 10,919 & 11,374 & 10,645 \\
\hline $\begin{array}{l}\text { Rata-rata Provinsi/ } \\
\text { Province Average }\end{array}$ & 9.11 & 9.21 & 7.01 & 8.44 & 13,429 & 11,809 & 27,794 & 17,677 \\
\hline
\end{tabular}

Sumber: BPS Provinsi Gorontalo, 2011 / Source : BPS Gorontalo Province, 2011 
Tipologi Klassen Produksi Perikanan dan Laju Pert. Eko. Sektor Perikanan Kab.Gorontalo, Kab.Boalemo, Kab.Pohuw ato dan Kab.Bone Bolango, Rata-rata 2008-2010

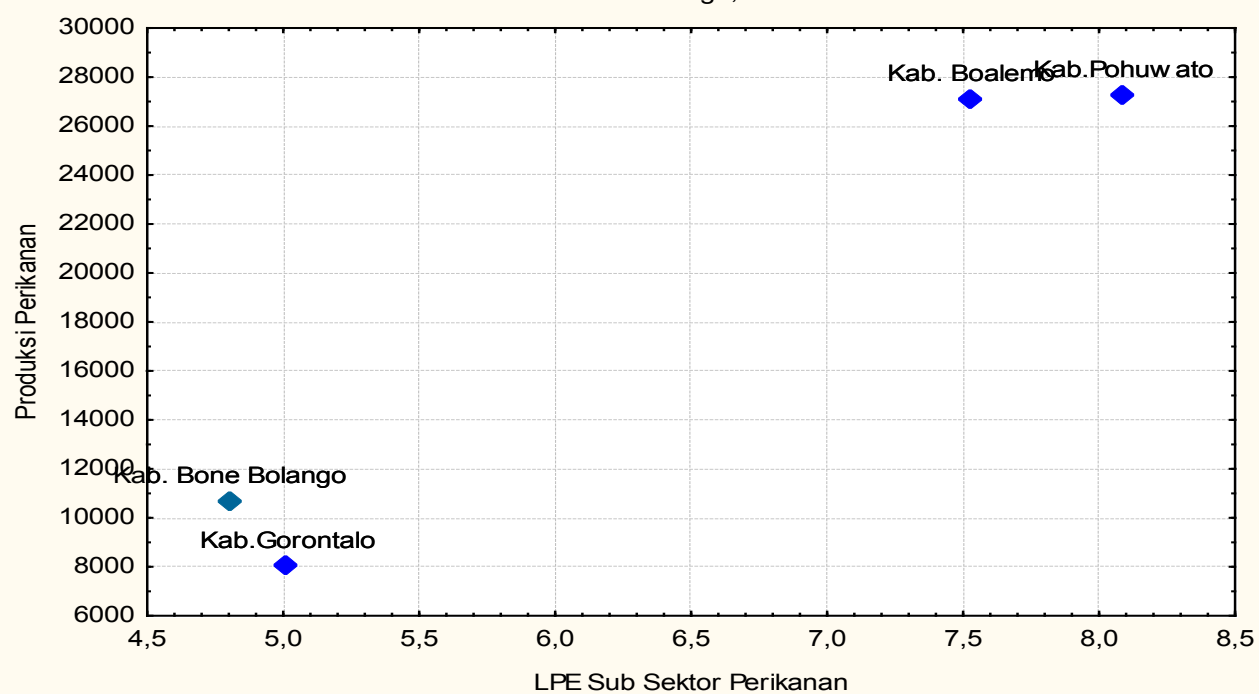

Gambar 2. Tipologi Klassen Subsektor Perikanan Provinsi Gorontalo, 2008-2010.

Figure 2. Typology Klassen Fisheries Sub-sector Gorontalo Province, 2008-2010.

Tabel 3. Matriks Tipologi Klassen Subsektor Perikanan Provinsi Gorontalo, 2008-2010.

Table 3. Typology Matrix Klassen Fishery Subsector Gorontalo Province, 2008-2010.

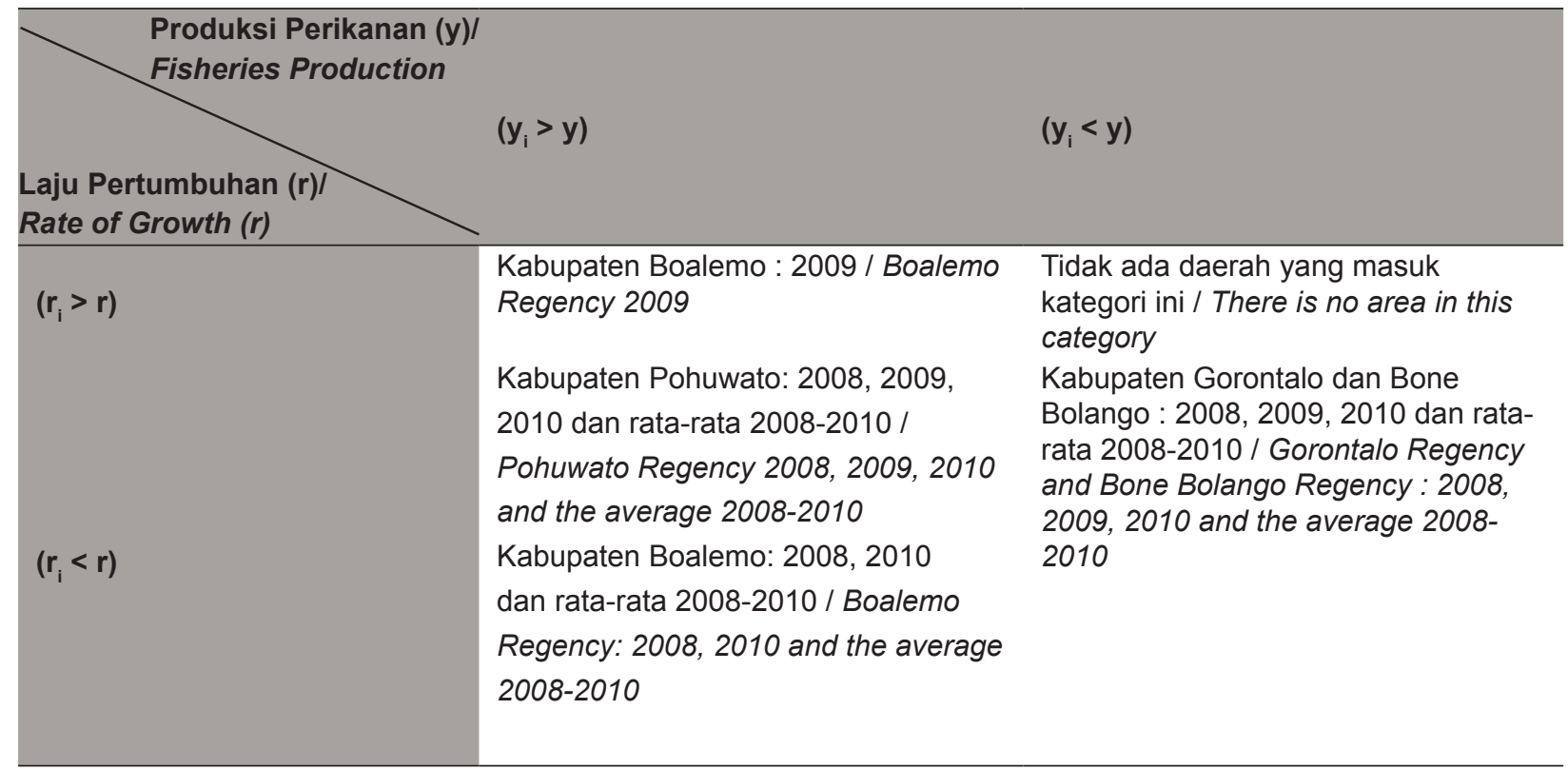

Sumber: Hasil Perhitungan, 2012 / Source : Calculation Result, 2012

Keterangan $: r \quad$ : Rata-rata LPE subsektor perikanan kabupaten / LPE average of fisheries sub-sector in district level

y : Rata-rata Produksi Perikanan Kabupaten / Average fisheries production of district level

$r_{i} \quad$ : LPE Subsektor Perikanan Kabupaten yang Diamati / LPE of fisheries sub-sector in district level

$y_{1}$ : Produksi Perikanan Kabupaten yang Diamati / Observed fisheries production of district level 
Kondisi perekonomian subsektor perikanan tidak memiliki perbedaan yang signifikan dengan kondisi perekonomian agregat khususnya bagi Kabupaten Gorontalo dan Bone Bolango. Kedua kabupaten ini berada pada kuadran IV yaitu daerah yang memiliki struktur perekonomian khususnya subsektor perikanan yang relatif tertinggal. Secara rata-rata selama tahun 2008-2010, keempat kabupaten ini tidak dapat mencapai struktur perekonomian subsektor perikanan yang cepat maju dan cepat tumbuh (kuadran I). Capaian posisi pada kuadran I hanya diraih oleh satu daerah saja yaitu Boalemo dan itupun hanya terjadi pada tahun 2009.

\section{Analisis Shift-share}

Shift-share analysis digunakan untuk menjelaskan kemampuan berkompetisi (competitiveness) aktifitas tertentu disuatu wilayah secara dinamis (Chunyun (2007), mengukur pertumbuhan lapangan kerja (Herath et al., 2011), membandingkan perubahan ekonomi dari sektor industri (Gebremedhin et al., 1995), pertumbuhan lapangan kerja, sektor pertanian, konstruksi, industri dan sektor jasa (Fernandez dan Menendez, 2005).

Dalam penelitian ini, wilayah referensi adalah Provinsi Gorontalo dan unit analisisnya adalah empat wilayah kabupaten yaitu Gorontalo,

Tabel 4. Nilai Koefisen Analisis Shift-Share Agregat (SSA) Provinsi Gorontalo, 2008-2010.

Table 4. Coefficient Values of Aggregate Shift-Share Analysis of (SSA) Gorontalo Province, 2008-2010.

\begin{tabular}{|c|c|c|c|c|c|c|c|c|c|}
\hline Uraian & 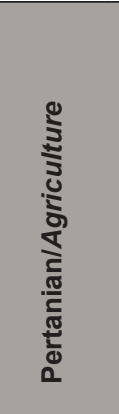 & 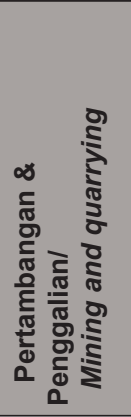 & 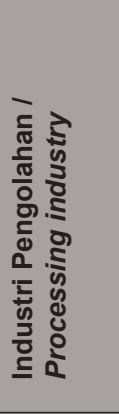 & 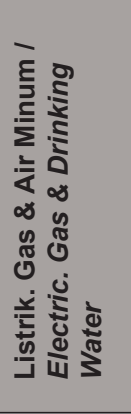 & 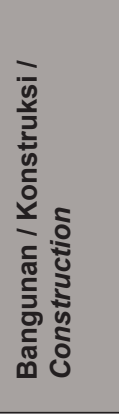 & 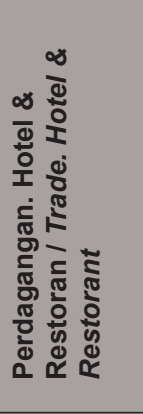 & 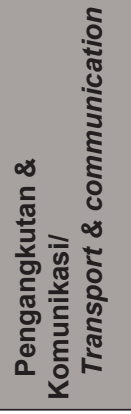 & 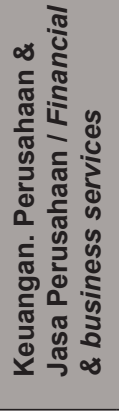 & 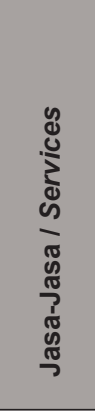 \\
\hline Regional Share & 0.157 & & & & & & & & \\
\hline $\begin{array}{l}\text { Proportional } \\
\text { Shift }\end{array}$ & -0.080 & 0.108 & -0.030 & -0.009 & 0.122 & 0.040 & 0.042 & 0.031 & 0.019 \\
\hline \multicolumn{10}{|l|}{ Differential Shift } \\
\hline $\begin{array}{l}\text { Kab. Gorontalo/ } \\
\text { Gorontalo } \\
\text { Regency }\end{array}$ & $\underline{0.058}$ & -0.033 & -0.030 & 0.043 & -0.036 & 0.013 & 0.006 & -0.046 & -0.033 \\
\hline $\begin{array}{l}\text { Kab. Boalemo/ } \\
\text { Boalemo } \\
\text { Regency }\end{array}$ & -0.035 & $\underline{0.254}$ & -0.057 & 0.065 & 0.0001 & 0.013 & 0.206 & 0.041 & -0.036 \\
\hline $\begin{array}{l}\text { Kab. Pohuwato/ } \\
\text { Pohuwato } \\
\text { Regency }\end{array}$ & 0.062 & -0.170 & 0.031 & -0.102 & -0.134 & -0.076 & -0.117 & -0.008 & $\underline{0.087}$ \\
\hline $\begin{array}{l}\text { Kab. Bone } \\
\text { Bolango/ } \\
\text { Bone Bolango } \\
\text { Regency }\end{array}$ & $\underline{0.082}$ & -0.123 & -0.046 & -0.127 & -0.182 & -0.105 & -0.129 & 0.069 & -0.064 \\
\hline \multicolumn{10}{|l|}{$\begin{array}{l}\text { Shift Share } \\
\text { Agregate }\end{array}$} \\
\hline $\begin{array}{l}\text { Kab. Gorontalo/ } \\
\text { Gorontalo } \\
\text { Regency }\end{array}$ & 0.135 & 0.233 & 0.098 & 0.192 & $\underline{0.243}$ & 0.210 & 0.206 & 0.142 & 0.143 \\
\hline $\begin{array}{l}\text { Kab. Boalemo/ } \\
\text { Boalemo } \\
\text { Regency }\end{array}$ & 0.043 & $\underline{0.519}$ & 0.071 & 0.213 & 0.279 & 0.211 & 0.405 & 0.229 & 0.140 \\
\hline $\begin{array}{l}\text { Kab. Pohuwato/ } \\
\text { Pohuwato } \\
\text { Regency }\end{array}$ & 0.139 & 0.095 & 0.159 & 0.046 & 0.145 & 0.121 & 0.082 & 0.180 & $\underline{0.264}$ \\
\hline $\begin{array}{l}\text { Kab. Bone } \\
\text { Bolango/ } \\
\text { Bone Bolango } \\
\text { Regency }\end{array}$ & 0.159 & 0.142 & 0.081 & 0.021 & 0.097 & 0.093 & 0.070 & $\underline{0.258}$ & 0.113 \\
\hline
\end{tabular}

Sumber: Hasil Perhitungan, 2012 / Source : Calculation Result, 2012

Ket: cetak garis bawah adalah sektor yang memiliki nilai tertinggi dalam wilayah; cetak tebal adalah nilai wilayah yang memiliki nilai tertinggi dalam setiap sektor. 
Boalemo, Pohuwato dan Bone Bolango. Hasil analisis ini akan menjelaskan kinerja (performance) keempat kabupaten tersebut dan membandingkannya dengan kinerjanya dalam wilayah Provinsi Gorontalo. Hasil dekomposisi pertumbuhan ekonomi di Provinsi Gorontalo seperti dalam Tabel 4.

Pada tahun 2010 terjadi pertumbuhan ekonomi di Provinsi Gorontalo sebesar 0,157 atau 15,7\% (396.819 juta) dari tahun 2008 yang ditunjukan oleh nilai koefisien regional share (Tabel 4). Nilai ini menunjukkan kontribusi pertumbuhan ekonomi provinsi terhadap kabupaten, khususnya untuk 4 kabupaten yang menjadi fokus penelitian yaitu Kabupaten Gorontalo, Boalemo, Pohuwato dan Bone Bolango (Tabel 5).

Dalam kurun waktu 2008-2010, hanya Kabupaten Gorontalo yang memiliki laju pertumbuhan ekonomi yang relatif sama dengan pertumbuhan provinsi, yaitu 15,7\%. Daerah lainnya memiliki nilai pertumbuhan ekonomi agregat masing-masing Kabupaten Pohuwato 15,1\%,
Kabupaten Boalemo 13,8\% dan Kabupaten Bone Bolango 13,6\%.

Khusus pertumbuhan sektor pertanian di Provinsi Gorontalo selama tahun 2008-2010 sebesar $7,7 \%$, terendah dibanding 8 sektor lain yang keseluruhannya memiliki pertumbuhan sebesar 2 digit. Dari kelima subsektor pendukung pertanian, pertumbuhan terbesar terjadi pada subsektor peternakan $(19,7 \%)$, perikanan $(16,9 \%)$ dan kehutanan $(16,6)$. Subsektor tanaman bahan makanan masih pada level $5,7 \%$ dan tanaman perkebunan justru mengalami penurunan sebesar $3,9 \%$.

\section{PERTUMBUHAN SUBSEKTOR PERIKANAN}

Selama kurun waktu 2008-2010, Kabupaten Boalemo, Pohuwato dan Bone Bolango memiliki pertumbuhan subsektor perikanan yang hampir sama yaitu $18,6 \%, 16,2 \%$ dan $12,7 \%$. Kabupaten Gorontalo hanya bertumbuh sebesar 7,4\% (Tabel 5). Hal ini tidak terlepas dari produksi subsektor perikanan Kabupaten Gorontalo yang hanya memiliki share $8 \%$ terhadap produksi perikanan.

Tabel 5. Nilai Koefisen Analisis Shift-Share pada Sektor Pertanian Provinsi Gorontalo, 2008-2010. Table 5. Coefficient Values of Shift-Share Analysis (SSA) in Agriculture sector Gorontalo Province, 2008-2010.

\begin{tabular}{|c|c|c|c|c|c|}
\hline $\begin{array}{c}\text { Uraian/ } \\
\text { Description }\end{array}$ & $\begin{array}{l}\text { Tanaman } \\
\text { Bahan } \\
\text { Makanan/ } \\
\text { Plant Food } \\
\text { Ingredients }\end{array}$ & $\begin{array}{l}\text { Tanaman } \\
\text { Perkebunan/ } \\
\text { Plantation } \\
\text { Crops }\end{array}$ & $\begin{array}{l}\text { Peternakan/ } \\
\text { Stockbreeding }\end{array}$ & $\begin{array}{l}\text { Kehutanan/ } \\
\text { Forestry }\end{array}$ & $\begin{array}{c}\text { Perikanan/ } \\
\text { Fishery }\end{array}$ \\
\hline Regional Share & & & & & 0.077 \\
\hline Proportional Shift & -0.020 & -0.116 & 0.120 & 0.089 & 0.091 \\
\hline \multicolumn{6}{|l|}{ Differential Shift } \\
\hline $\begin{array}{l}\text { Kab. Gorontalo/ } \\
\text { Gorontalo Regency }\end{array}$ & 0.102 & 0.135 & -0.065 & $\underline{0.143}$ & -0.095 \\
\hline $\begin{array}{l}\text { Kab. Boalemo/ } \\
\text { Boalemo Regency }\end{array}$ & -0.058 & 0.035 & -0.103 & $\underline{0.777}$ & 0.018 \\
\hline $\begin{array}{l}\text { Kab. Pohuwato/ } \\
\text { Pohuwato Regency }\end{array}$ & $\underline{0.113}$ & 0.098 & -0.051 & -0.128 & -0.006 \\
\hline $\begin{array}{l}\text { Kab. Bone Bolango/ } \\
\text { Bone Bolango Regency }\end{array}$ & $\underline{0.183}$ & 0.135 & -0.061 & -0.025 & -0.042 \\
\hline \multicolumn{6}{|l|}{ SSA } \\
\hline $\begin{array}{l}\text { Kab. Gorontalo/ } \\
\text { Gorontalo Regency }\end{array}$ & 0.159 & 0.096 & 0.132 & $\underline{0.309}$ & 0.074 \\
\hline $\begin{array}{l}\text { Kab. Boalemo/ } \\
\text { Boalemo Regency }\end{array}$ & -0.001 & -0.003 & 0.095 & $\underline{0.943}$ & 0.186 \\
\hline $\begin{array}{l}\text { Kab. Pohuwato/ } \\
\text { Pohuwato Regency }\end{array}$ & $\underline{0.170}$ & 0.059 & 0.146 & 0.038 & 0.162 \\
\hline $\begin{array}{l}\text { Kab. Bone Bolango/ } \\
\text { Bone Bolango Regency }\end{array}$ & $\underline{0.240}$ & 0.096 & 0.136 & 0.141 & 0.127 \\
\hline
\end{tabular}

Sumber: Hasil Perhitungan / Source: Results of Calculation

Ket: cetak garis bawah adalah sektor yang memiliki nilai tertinggi dalam wilayah;

cetak tebal adalah nilai wilayah yang memiliki nilai tertinggi dalam setiap sektor 
Komponen kedua dalam analisis shift share adalah proportionality shift. Dari komponen ini diperoleh hasil bahwa terdapat 3 sektor yang memiliki pertumbuhan dibawah pertumbuhan provinsi (pertumbuhan negatif), yaitu sektor pertanian, industri pengolahan serta listrik, gas dan air minum (Tabel 4). Dengan kata lain ketiga sektor tersebut aktivitas ekonominya tumbuh lebih lambat dibanding aktivitas ekonomi provinsi.

Setiap sektor dalam proportionalty shift pada masing-masing kabupaten dapat dihitung besarnya nilai peningkatan/penurunan dengan mengalikan setiap nilai koefisiennya dengan nilai PDRB sektor pada masing-masing kabupaten dan kota. Total hasil penjumlahannya untuk setiap kabupaten/kota menunjukan dampak dari bauran industri (industrial mix). Jika positif, berarti bauran industri berdampak positif terhadap perekonomian kabupaten yang bersangkutan, demikian sebaliknya. Berdasarkan perhitungan diperoleh hasil bahwa tidak ada daerah yang memiliki dampak positif dengan adanya bauran industri. Hal ini berarti bahwa pertumbuhan aktivitas ekonomi yang positif pada sektor pertambangan, bangunan, perdagangan, pengangkutan, keuangan dan jasa bagi semua daerah tidak mampu menciptakan aktivitas perekonomian secara agregat yang tumbuh lebih cepat dan terspesialisasi dibanding aktivitas Provinsi Gorontalo secara agregat.

Analisis subsektor menunjukan bahwa subsektor perikanan memilikikoefisien pertumbuhan yang positif, tetapi bauran industri yang memberi efek positif bagi sektor pertanian secara agregat hanya terjadi pada Kabupaten Gorontalo dan Bone Bolango. Hal ini cenderung disebabkan kontribusi PDRB dari subsektor peternakan yang memiliki kontribusi lebih besar dari subsektor perikanan.

Pada analisis differential shift, komponen yang menggambarkan pertumbuhan ekonomi daerah pada setiap sektor karena kondisi spesifik daerah yang kompetitif. Hasil dekomposisi pertumbuhan pada komponen ini juga dapat menggambarkan perbedaan struktur ekonomi dalam setiap wilayah pada masing-masing sektor. Berikut adalah hasil analisis differential shift pada masing-masing daerah.

\section{a. Kabupaten Gorontalo}

Kabupaten Gorontalo kompetitif pada empat sektor, yaitu sektor pertanian, listrik, perdagangan dan pengangkutan. Sektor perdagangan merupakan sektor yang memiliki koefisien terbesar diantara sektor lainnya dan sekaligus memiliki tingkat kompetitif yang lebih besar dibanding daerah lainnya. Hal ini disebabkan oleh posisi yang strategis yaitu dekat dengan ibukota provinsi serta berada pada jalur trans Sulawesi, selain itu daerah tersebut merupakan salah satu pusat ekonomi di Gorontalo sebelum pemekaran provinsi.

Kompetitif daerah ini pada sektor pertanian ternyata masih lebih rendah dibanding Kabupaten Pohuwato dan Kabupaten Bone Bolango. Hal ini kontradiktif dengan potensi kepemilikan areal sawah Kabupaten Gorontalo yang mencakup $65 \%$ dari total sawah di Provinsi Gorontalo dan areal bukan sawah sebesar 25\%. Rendahnya tingkat kompetetif ini disebabkan oleh kecilnya produksi perikanan yang hanya mencapai rata-rata $8 \%$ dari produksi provinsi selama tahun 2008-2010. Bila dibandingkan dengan Kabupaten Pohuwato dan Bone Bolango yang mencapai $26 \%$ dan $10 \%$ dari total produksi perikanan Provinsi Gorontalo. Secara parsial, meskipun sektor pertanian cukup kompetitif tetapi subsektor perikanan bukan merupakan subsektor yang kompetitif, dengan koefisien differential shift yang bernilai negatif.

Dari hasil perhitungan differential shift agregat diperoleh hasil bahwa pertumbuhan Kabupaten Gorontalo naik sebesar $1.119,66$ juta rupiah atau secara agregat perekonomian Kabupaten Gorontalo kompetitif. Jadi, meskipun Kabupaten Gorontalo hanya memiliki 4 sektor yang kompetitif termasuk sektor pertanian, tetapi akumulasi pertumbuhan PDRB dari keempat sektor tersebut dapat mengimbangi besarnya nilai sektor yang tidak kompetitif.

b. Kabupaten Boalemo

Sektor yang kompetitif adalah 6 sektor yaitu pertambangan, listrik, bangunan, perdagangan, pengangkutan dan keuangan. Sektor pertambangan merupakan sektor dengan nilai koefisien competitiveness yang terbesar dari seluruh sektor pada empat kabupaten ini. Berbeda dengan Kabupaten Gorontalo, meskipun memiliki 6 sektor yang kompetitif tetapi secara agregat perekonomian Boalemo tidak kompetitif. Kontribusi pertumbuhan ekonomi yang diberikan justru memberikan efek penurunan sebesar 1.209,63 juta rupiah. 
Dekomposisi pertumbuhan dari komponen ini memberikan nilai negatif karena sektor yang tidak kompetitif justru memiliki kontribusi PDRB terbesar (sektor pertanian memiliki kontribusi PDRB 37\% dan sektor jasa 17\%). Tingkat competitiveness parsial maupun share produksi dari subsektor perikanan tidak mampu mendorong pertumbuhan ekonomi secara agregat maupun terhadap sektor pertanian itu sendiri. Padahal Kabupaten Boalemo bersama-sama Pohuwato memiliki share masing-masing $26 \%$ terhadap total produksi perikanan di Provinsi Gorontalo.

c. Kabupaten Pohuwato

Jumlah sektor yang kompetitif Kabupaten Pohuwato lebih sedikit dibandingkan yang dimiliki oleh Kabupaten Boalemo sebagai daerah induk sebelum daerah ini menjadi kabupaten tersendiri. Sektor yang kompetitif hanya terdiri dari 3 sektor yaitu sektor pertanian, industri pengolahan dan jasa, namun daerah ini secara umum menghasilkan kontribusi competitiveness bagi perekonomiannya. Hal ini tidak terlepas dari share sektor pertanian sebagai kontributor terbesar pertumbuhan (45\%) yang memiliki koefisien positif serta dukungan sektor jasa dengan share PDRB $12 \%$ dan sektor industri pengolahan dengan share 6\%. Akumulasi nilai absolut ketiga sektor ini mampu membawa perekonomian Pohuwato kompetitif secara agregat dan mengalami pertumbuhan/pergeseran ekonomi bagi Kabupaten Pohuwato berupa peningkatan pertumbuhan sebesar 5.545,91 juta rupiah.

Dari tabel SSA sektor pertanian, Kabupaten Pohuwato harus lebih meningkatkan tingkat kompetitif subsektor perikanan karena subsektor ini belum kompetitif dibanding daerah lainnya di Gorontalo. Sektor pertanian lebih ditunjang oleh subsektor tanaman bahan makanan dan tanaman perkebunan.

d. Kabupaten Bone Bolango

Sektor kompetitif yang dimiliki hanya pada sektor pertanian dan keuangan. Meskipun sektor pertanian dan keuangan Bone Bolango merupakan sektor dengan koefisien competitiveness tertinggi dibanding sektor pertanian dan keuangan yang dimiliki daerah lainnya, tetapi dukungan kedua sektor ini tidak mampu memberikan pengaruh positif terhadap pertumbuhan ekonomi daerahnya. Akumulasi nilai pertumbuhan komponen ini memberikan penurunan sebesar $4.318,45$ juta rupiah terhadap perekonomian daerah.

Banyaknya sektor yang tidak kompetitif dimungkinkan oleh kondisi daerah yang umumnya memiliki potensi yang relatif dibawah jika dibandingkan dengan daerah lainnya. Misalnya untuk daya dukung sektor pertanian dari aspek pemilikan lahan, daerah ini hanya memiliki $6 \%$ areal persawahan dan $15 \%$ areal non sawah dari total provinsi, serta rata-rata produksi hasil pertanian yang relatif rendah dibanding kabupaten lainnya di Gorontalo. Daya dukung subsektor perikanan rata-rata setiap tahun hanya $10 \%$ dari total produksi perikanan provinsi. Seperti halnya Pohuwato, daerah ini lebih bertumpu pada tingkat kompetitif subsektor tanaman bahan makanan dan tanaman perkebunan. Selain itu juga aspek infrastruktur pendukung pembangunan yang relatif masih kurang.

Dari hasil SSA yang mencakup Regional Share, Proportionality Shift dan Differential Shift, dinamika yang terjadi antar wilayah di Provinsi Gorontalo disebabkan oleh:

- Kabupaten Boalemo dan Bone Bolango: pergeseran struktur ekonomi secara agregat lebih disebabkan oleh dinamika yang terjadi di Provinsi Gorontalo, dengan kata lain perekonomian secara agregat tumbuh tidak terspesialisasi dan tidak kompetitif. Pertumbuhan ekonomi agregat yang positif masih sepenuhnya tergantung pada daya dukung perekonomian provinsi.

- Kabupaten Gorontalo dan Pohuwato: pergeseran struktur ekonomi secara agregat disebabkan oleh dinamika yang terjadi di Provinsi Gorontalo (regional share) dan dinamika sektor daerahnya itu sendiri (differential shift), dengan kontribusi terbesar masih dipegang oleh regional share. Akumulasi sektor yang kompetitif telah memberikan dorongan bagi kompetitifnya ekonomi daerah secara agregat. 


\section{PENUTUP}

Kabupaten Pohuwato memiliki nilai PDRB perkapita di atas provinsi, namun pertumbuhan ekonominya masih dibawah provinsi (high income but low growth atau kategori maju tapi tertekan). Kabupaten Gorontalo, Boalemo dan Bone Bolango termasuk dalam kategori relatif tertinggal (low growth and low income). Pada subsektor perikanan, Kabupaten Gorontalo dan Bone Bolango berada pada kuadran IV (relatif tertinggal). Boalemo mampu mencapai kuadran I tetapi itu hanya terjadi tahun 2009. Ini berarti selama tahun 2008 - 2010 tidak ada kabupaten yang konsisten menempatkan subsektor perikanan pada kuadran I atau kategori cepat maju dan cepat tumbuh.

Langkah yang perlu diambil untuk meningkatkan pertumbuhan ekonomi yang berkaitan dengan sektor perikanan adalah sebagai berikut: (a) Menyediakan fasilitas publik yang berkaitan dengan peningkatan aktivitas ekonomi yang berkaitan dengan sektor perikanan; (b) Pengembangan sektor tersebut hendaknya dilakukan secara terintegrasi, dimana pada akhirnya dapat meningkatkan penerimaan masyarakat maupun Pemerintah Daerah; (c) Pengembangan industri pengolahan, sebaiknya didukung oleh potensi sumberdaya yang dimiliki, sehingga industri yang dikembangkan bertumpu pada kekuatan daerah dan mempunyai keterkaitan kebelakang maupun kedepan yang kuat agar tercipta struktur ekonomi yang kuat; (d) Khusus untuk industri kecil terutama komoditi dengan ciri khas wilayah perlu ditindak lanjuti dengan kebijakan dalam hal permodalan, teknik produksi, dan pemasaran. Kebijakan ini dapat berupa pelatihan, penyediaan informasi pasar, dukungan dinas terkait, lembaga keuangan, lembaga pengembangan swadaya masyarakat, swasta dan perguruan tinggi, sehingga komoditi khas yang dihasilkan dari industri kecil dapat berkompetisi dipasar; dan (e) Pemerintah Daerah Kabupaten Boalemo dan Pohuwato perlu tindakan pro aktif dan konstruktif untuk merangsang tumbuhnya minat penanaman modal di daerah disertai dengan peningkatan dan pembenahan kualitas SDM melalui penyuluhan dan pelatihan untuk menciptakan tenaga kerja bidang perikanan yang berkualitas.

Pengembangan wilayah dengan pendekatan minapolitan sebagai konsep pembangunan perikanan tidak bisa dilakukan secara parsial. Perikanan harus dibangun secara holisitik yaitu dengan membangun semua yang tersedia di perkotaan ke perdesaan.

\section{DAFTAR PUSTAKA}

Badan Pusat Statistik Provinsi Gorontalo. Gorontalo Dalam Angka 2008; 2009; 2010 dan 2011. Gorontalo: BPS Provinsi Gorontalo.

Blakely, E.J. and Leigh, N.G. 2010. Planning Local economic Development. Theory and Practice. 4th Ed. Sage Publication.

Budd, L., and S. Whimster, 2005. Global Financing: A Study of Metropolitan Change. London \& New York. Taylor \& Francis, 369p.

Chunyun, S.; Z. Jie; Y. Yang and Z. Zhang. 2007. Shift-share Analysis on International Tourism Competitiveness-A Case of Jiangsu Province. Chinese Geographical Science. 17(2): 173-178.

Dinas Kelautan dan Perikanan Provinsi Gorontalo. 2011. Rencana Aksi Pembangunan Perikanan Koridor Ekonomi Sulawesi. Gorontalo: DKP Gorontalo.

Fernandez, M.M., and A.J.L. Menendez. 2005. Spatial Shift Share Analysis: new development and new findings for the Spanish case. 45th Congress of the European Regional Science Association.

Gebremedhin, T.W., and D.A. Lass. 1995. A Shift-share analysis of employment growth in West Virginia and Massachusetts. Paper presented at the Northeastern Agricultural and Resource Economics Association annual meeting, Vermont, June 18-20.

Glasson, J. 1990. Pengantar Perencanaan Regional. Terjemahan. Jakarta: LPFEUI.

Herath, J., T.G. Gebremedhin and B.M. Maumbe. 2011. A Dynamic Shift-Share Analysis of Economic Growth in West Virginia. Journal of Rural and Community Development. 6 (2) : 155-169.

Hidayati, R.A. 2008. Analisis Ketimpangan Ekonomi antar Kecamatan di Kabupaten Gresik. Jurnal Logos. 6 (1) : 83-97.

Kementerian Kelautan dan Perikanan. 2010. Keputusan Menteri Kelautan dan Perikanan Republik Indonesia No. 32/Men/2010 tentang Penetapan Kawasan Minapolitan. Jakarta.

2011. Keputusan Menteri Kelautan dan Perikanan Republik Indonesia No. Kep. 18/Men/2011 tentang Pedoman Umum Minapolitan. Jakarta. 
2011. Keputusan Menteri Kelautan dan Perikanan Republik Indonesia No. Kep. 39/Men/2011 tentang Perubahan atas Keputusan Menteri Kelautan dan Perikanan No. Kep. 32/Men/2010 tentang Penetapan Kawasan Minapolitan. Jakarta.

Lewis, R. 2004. Suburbs: Building Work and Home on the Metropolitan Fringe. Philadelphia: Temple University Press. 294p.

Priana, W. dan S.N. Farida. 2005. Analisis Tipologi Klassen di Tiga Negara Asia (Indonesia, India dan Cina). Jumal IImu-IImu Ekonomi.5 (2) : 76-81.

Razin, E., M. Dijst, and C. Vazquest, 2007. Employment Deconcentration in European Metropolitan Areas: Market Forces versus Planning Regulations. Dordrecht, The Netherlands: Springer., 297p.
Robinson, T. 2005. Ekonomi Regional Teori dan Aplikasi. Jakarta: Bumi Aksara.

Rustiadi, E. dan S. Hadi. 2004. Pengembangan Agropolitan Sebagai Strategi Pembangunan Perdesaan dan Pembangunan Berimbang. Bogor: Crespent Press.

Sjafrizal. 1997. Pertumbuhan Ekonomi dan Ketimpangan Regional Wilayah Indonesia Bagian Barat. Prisma, LP3ES, No.3.

Sutikno dan Maryunani. 2007. Analisis Potensi dan Daya Saing Kecamatan Sebagai Pusat Pertumbuhan Satuan Wilayah Pengembangan (SWP) Kabupaten Malang. Journal of Indonesian Applied Economics. 1 (1): 1-17.

Wijaya, B. dan H.D. Atmanti. 2006. Analisis Pengembangan Wilayah dan Sektor Potensial Guna Mendorong Pembangunan di Kota Salatiga. Dinamika Pembangunan. $2: 101-118$. 